\title{
A Comparative Study of Mechanical and Tribological Properties of AISI-304 and AISI-316 Submitted to Glow Discharge Nitriding
}

\author{
Fabiana Cristina Nascimento $^{\mathrm{b}}$, Carlos Eugênio Foerster ${ }^{\mathrm{b}}$, Silvio Luiz Rutz da Silva ${ }^{\mathrm{b}}$, \\ Carlos Mauricio Lepienski*, Carlos José de Mesquita Siqueira ${ }^{\mathrm{c}}$, Clodomiro Alves Junior ${ }^{\mathrm{d}}$ \\ a Departamento de Física - UFPR, CP 19044, 81531-990 Curitiba - PR, Brazil \\ ${ }^{\mathrm{b}}$ Departamento de Física - UEPG, 84030-900 Ponta Grossa - PR, Brazil \\ 'Departamento de Engenharia Mecânica - UFPR, CP 19011, 81531-990 Curitiba - PR, Brazil \\ ${ }^{\mathrm{d}}$ Departamento de Física - UFRN, 59072-970 Natal - RN, Brazil
}

Received: December 17, 2008; Revised: April 17, 2009

\begin{abstract}
Mechanical and tribological properties of AISI 304 and AISI 316 stainless steels submitted to glow discharge ion nitriding are reported. The atmosphere was $20: 80-\mathrm{N}_{2}: \mathrm{H}_{2}$ with substrate temperatures ranging from 300 to $500{ }^{\circ} \mathrm{C}$. Treatment at $300{ }^{\circ} \mathrm{C}$ produced expanded austenite $\left(\gamma_{\mathrm{N}}\right)$ in both steels. Increasing the temperature, the phases $\gamma-\mathrm{Fe}_{4} \mathrm{~N}$ and $\varepsilon-\mathrm{Fe}_{2+x} \mathrm{~N}$ were present and the latter is the major phase for AISI 304 . At $500{ }^{\circ} \mathrm{C}$, the $\mathrm{CrN}$ phase was also identified in both steels. Hardnesses of about 13-14 GPa at near surface regions were obtained in both steels. Moreover, AISI 316 nitrided at $500{ }^{\circ} \mathrm{C}$ has the deepest hard layer. Tribological tests showed that wear can be reduced by up to a factor of six after the nitriding processes, even for a working temperature of $300{ }^{\circ} \mathrm{C}$. The profiles during and after nanoscratch tests did not reveal significant differences after nitriding processes in both steels.
\end{abstract}

Keywords: nitriding, mechanical properties, austenitic steels, hardness

\section{Introduction}

AISI 304 and AISI 316 are austenitic stainless steels widely employed in corrosive environments. The main difference between these two steels is with respect to the content of alloying element molybdenum. The amount of Mo in AISI 316 corresponds to about $2 \%$ in weight while it is absent in AISI 304.

Nitrogen ion beam based processes such as glow discharge (GD) and plasma immersion ion implantation (PI3) are indicated to improve mechanical, tribological and corrosive resistances of metals alloys $^{1-8}$. The ion beam nitriding processes promotes the presence of embedded nitride precipitates at the surface. The hardness of the modified layers can reach values up to $15 \mathrm{GPa}$, while untreated austenitic steels have a hardness of about 2-3 $\mathrm{GPa}^{9}$. The modified surface layer thickness, degree of roughness and hardness depend on process parameters (atmosphere composition, working temperature and processing time).

Ion beam nitriding processes often produce a thin modified surface that ranges in thickness from micrometers to tenths of a micrometer ${ }^{10}$. As a consequence, the use of instrumented indentation is indicated to obtain hardness and elastic modulus profiles from nano to microscale. Another point to consider is the graded or depth-dependent stoichiometry of the nitrogen precipitates in the modified layer. Expanded austenite and full-fold nitrogen precipitate stoichiometries can be present. In addition a nitrogen diffusion layer at greater depths is expected. The main effect of this graded surface can be understood by regarding the structure as a hard layer over a soft substrate that influences the measured hardness of the modified layer ${ }^{11-13}$. It is common in hardness measurements to obtain the values using a cross-section of the modified layer. Consequently, the influence of the substrate is almost absent. For practical applications, however, the surface is always submitted to surface normal and tangential applied loads. Moreover, in thin layers this methodology cannot be applied. The mechanical response for external loads is then better simulated by instrumented indentation performed on ion beam modified surfaces rather than on cross-sections.

In the present work we report a comparative study about structural, mechanical and tribological properties of AISI 304 and AISI 316 stainless steels submitted to nitrogen glow discharge at different substrate temperatures from 300 to $500{ }^{\circ} \mathrm{C}$. Structural characterization was evaluated by $\mathrm{X}$ ray diffraction (Bragg-Brentano geometry) using Rietveld refinement. Hardness, elastic modulus profiles and surface topography were obtained by instrumented indentation. Conventional Vickers measurements were also employed in order to obtain deeper hardness profiles. Tribological and wear behavior were studied by reciprocating sliding tests.

\section{Experimental Procedure}

Commercial sheets of AISI 304 (Ni 8.63\%, Cr 16.04\%, C 0.047\%, Si $0.48 \%$, Mn $1.37 \%$, S $0.005 \%$, Mo $0.09 \%$, P $0.029 \%$ weight, with Fe being the balance) and commercial rods of AISI 316 (Ni 11.64\%, Cr $15.68 \%$, C $0.10 \%$, Si $0.34 \%$, Mn $1.73 \%$, S $0.031 \%$, Mo $1.86 \%$, P $0.029 \%$ weight with Fe being the balance) were cut in $1.5 \times 1.5 \times$ $0.5 \mathrm{~cm}$ and $\phi=3 \mathrm{~cm}$ and $0.5 \mathrm{~cm}$ thick pieces, respectively. The samples were mechanically polished up to $1 / 4 \mu \mathrm{m}$ diamond paste in order to obtain a final mirror finish.

DC glow discharge was performed in $\mathrm{N}_{2}: \mathrm{H}_{2}-20: 80$ atmosphere at $600 \mathrm{~Pa}$ with prior $\mathrm{H}_{2}$ sputtering at $100{ }^{\circ} \mathrm{C}$ during 2 hours. The plasma current ranged from 200 to $300 \mathrm{~mA}$, resulting in sample ensembles with substrate temperatures of 300,400 and $500{ }^{\circ} \mathrm{C}$. The temperature was controlled by monitoring a backside thermocouple and adjusting the plasma current as needed. All samples were nitrided during four hours. 
The phases were identified by $\mathrm{X}$ ray diffraction data (XRD) collected at $20^{\circ} \leq 2 \theta<100^{\circ}$ with $\mathrm{Cu} \mathrm{K}_{\alpha},(\lambda=1.5406 \AA), 40 \mathrm{kV}, 20 \mathrm{~mA}$ using step sizes of $0.02^{\circ}$ and 5 seconds of counting time. The crystalline planes of phases $\gamma$ ' $-\mathrm{Fe}_{4} \mathrm{~N}, \varepsilon-\mathrm{Fe}_{2+\mathrm{x}} \mathrm{N}$ and $\mathrm{CrN}$ were indexed using Joint Committee on Powder Diffraction Standards (JCPDS) cards and the Inorganic Crystal Structure Database (ICSD). In particular the $\gamma_{\mathrm{N}}$-nitrogen expanded austenite was identified using literature data ${ }^{14-21}$. The structural characterization was performed using the Rietveld method $^{22}$ and the crystal structure of each phase was obtained using FullProf-suite software ${ }^{23}$. Peak shape, width $(U, V, W)$ parameters and background were considered. All theses parameters were refined adopting an iterative least-squares approach through minimization of the residual parameter. The peak shape function used in all analysis was the pseudo-Voigt.

Instrumented indentation was employed to obtain hardness and elastic modulus profiles at shallow depths according to the Oliver and Pharr method ${ }^{13}$. The maximum applied loads were $400 \mathrm{mN}$ and the diamond indenter was of the Berkovich type. For deeper hardness profiles, conventional Vickers hardness measurements were performed with loads in the range 0.5 to $5 \mathrm{~N}$. Roughness was analyzed from stylus profilometry performed by the same instrumented indentation device at loads on the order of $300 \mu \mathrm{N}$. Nanosctrach tests in ramping loads from 0 to $400 \mathrm{mN}$ following the tip edge direction were performed with the Berkovich tip. The length of the nanoscratch tests was $1 \mathrm{~mm}$. The tip penetration profiles were monitored before, during and after the scratch. The profiles during the loading and the elastic recovery were determined taking into account the original surface topography.

The wear tests (reciprocating sliding) were performed under severe dry conditions at room temperature and $\sim 50 \%$ of humidity. The counter body was a WC $(\mathrm{Co})$ ball $(\phi=6 \mathrm{~mm})$ with a load of $5.0 \mathrm{~N}$. The sliding velocity was $1 \mathrm{~cm} / \mathrm{s}$, with half-amplitude of $1.0 \mathrm{~mm}$ and integrated sliding distance of $9.0 \mathrm{~m}$ that corresponds to $2.25 \times 10^{3}$ cycles.

\section{Results and Discussion}

In the sequence are presented and discussed the results starting by the structural modifications due to nitriding in both steels.

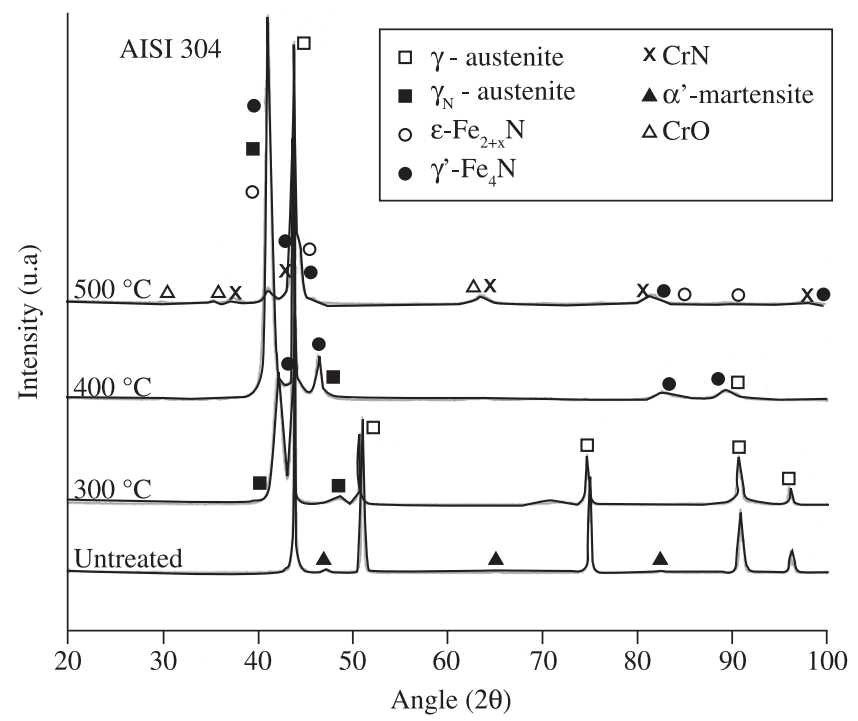

(a)

\subsection{Structure features}

Figure 1a-b shows the $\mathrm{X}$ ray diffraction patterns for AISI 304 and AISI 316 steels for untreated and nitrided samples. Both untreated steels have the typical austenitic structure identified by JCPDS cards. Lattice parameters of AISI 304 and AISI 316 austenitic phase were respectively: 3.5918(1) $\AA$ and 3.5935(1) $\AA$. This phase was present at all nitriding working temperatures, however a reduction of the volume fraction is observed with increasing working temperature. A small amount of $\alpha^{\prime}$-martensitic phase induced during the mechanical polishing process was detected in the untreated samples. The presence of this phase was more evident in AISI 304 steel (Figure 1a-b), which can be attributed to the higher content of Ni in AISI 316. The nitriding at $300{ }^{\circ} \mathrm{C}$ produces the $\gamma_{\mathrm{N}}$ - nitrogen expanded austenite as predominant phase in both alloys. This phase presented broad peaks at angles smaller than those for (111) $\gamma$ and (200) $\gamma$, and is associated with a nitrogen-rich austenitic structure. Pronounced preferential orientations $(111) \gamma_{\mathrm{N}}$ and $(200) \gamma_{\mathrm{N}}$ were observed.

A mixture of different nitride stoichiometries $\left(\varepsilon-\mathrm{Fe}_{2+\mathrm{x}} \mathrm{N}, \gamma-\mathrm{Fe}_{4} \mathrm{~N}\right.$ and $\mathrm{CrN}$ ) was formed at 400 and $500{ }^{\circ} \mathrm{C}$ independently of steel composition. Coexistent phases $\gamma_{\mathrm{N}} \gamma-\mathrm{Fe}_{4} \mathrm{~N}$ (cubic structure), and $\varepsilon-\mathrm{Fe}_{2+\mathrm{x}} \mathrm{N}$ (hexagonal structure) as predominant (Figure 1a) were identified in AISI 304 steel. Theses phases also were observed in AISI 316 steel (Figure 1b) with the $\gamma-\mathrm{Fe}_{4} \mathrm{~N}$ nitride as the predominant one. At $500{ }^{\circ} \mathrm{C}$ $\mathrm{CrN}$ and $\mathrm{CrO}$ (small contribution) phases were also identified in both steels in addition to the iron nitrides. The presence of $\mathrm{CrO}(2 \theta=30.05$, 34.17 and $62.89^{\circ}$, AISI 304 ) is probably due to a residual presence of oxygen in the plasma chamber.

Rietveld refinement was performed for all samples. The results for the different phases, structural planes, lattice parameters and compositions are shown in Tables 1 and 2. In samples nitrided at $300{ }^{\circ} \mathrm{C}$ the expanded austenite was identified in both steels. The nitrogen expanded austenite structure presents a crystallographic structure that is not completely understood. Recent work ${ }^{24}$ showed that this phase may be represented by 10 plausible candidate structures (cubic, tetragonal, monoclinic, rhombohedral, triclinic, etc...). The actual presence of these structures depends on a combination of effects such as stacking faults in the fcc lattice, the working temperature and the nitrogen content in the austenite structure. In our

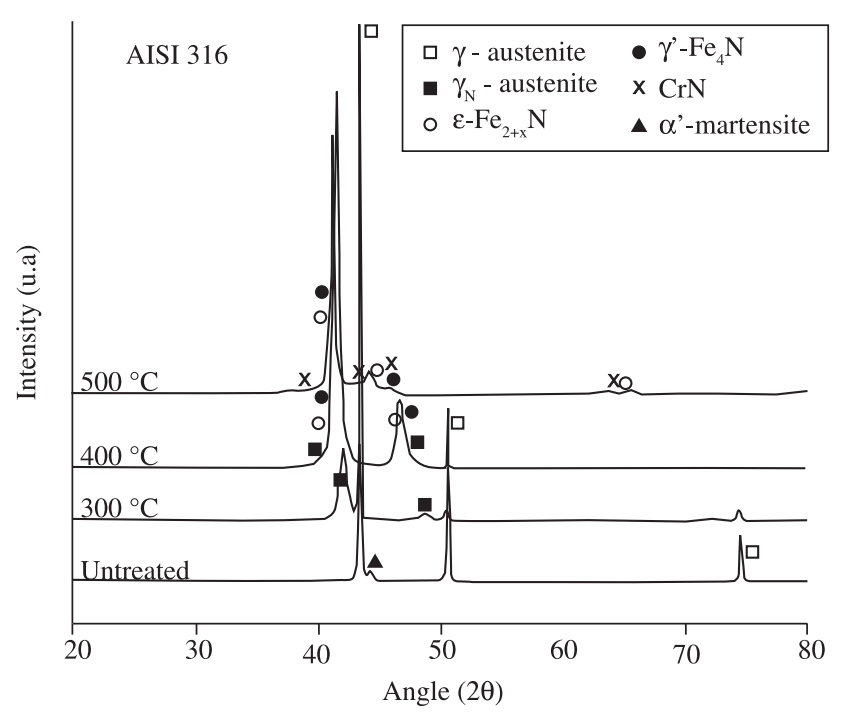

(b)

Figure 1. X ray diffractions patterns for samples of AISI 304 (a) and AISI 316, (b) both untreated and nitrided at 300 , 400 and $500{ }^{\circ} \mathrm{C}$. 
Table 1. Phases, lattice parameters, space group and symmetry for untreated and nitrided AISI 304.

\begin{tabular}{|c|c|c|c|c|}
\hline \multicolumn{5}{|c|}{ AISI 304} \\
\hline Temperature & Phases & JCPDS-ICSD-Reference & Lattice parameter & $(\mathrm{hkl})$ \\
\hline \multirow[t]{2}{*}{ Untreated } & $\gamma$-austenite & Card: 33:0397 & $\mathrm{a}=3.5918(1)$ & $\begin{array}{c}111-200-220 \\
311-222\end{array}$ \\
\hline & $\alpha$ '-martensite & Card: $35: 1375$ & $\mathrm{a}=2.8729(4)$ & $110-200-211$ \\
\hline \multirow[t]{2}{*}{$300^{\circ} \mathrm{C}$} & $\gamma$-austenite & Card: 33:0397 & $\mathrm{a}=3.5919(2)$ & $\begin{array}{c}111-200-220 \\
311-222\end{array}$ \\
\hline & $\gamma_{\mathrm{N}}$-austenite & References ${ }^{10-17}$ & $3.7171(4)$ & $111-200$ \\
\hline \multirow[t]{4}{*}{$400^{\circ} \mathrm{C}$} & $\gamma$-austenite & Card: 33:0397 & $3.5613(2)$ & $111-311$ \\
\hline & $\gamma_{\mathrm{N}}$-austenite & References $^{10-17}$ & $3.7264(4)$ & $111-200$ \\
\hline & $\gamma^{\prime}-\mathrm{Fe}_{4} \mathrm{~N}$ & $\begin{array}{l}\text { Card: 03:0964 } \\
\text { Card: 03:0958 }\end{array}$ & $3.7982(3)$ & $\begin{array}{c}200-210-311 \\
222\end{array}$ \\
\hline & $\varepsilon-\mathrm{Fe}_{2+\mathrm{x}} \mathrm{N}$ & $\begin{array}{l}\text { Card: 03:0925 } \\
\text { ICSD: } 93173\end{array}$ & $\mathrm{c}=4.6461(1)$ & $\begin{array}{c}00.2-10.1-20.0 \\
01.2-04.0\end{array}$ \\
\hline \multirow[t]{5}{*}{$500^{\circ} \mathrm{C}$} & $\gamma$-austenite & Card: 33:0397 & $3.5628(9)$ & 111 \\
\hline & $\gamma^{\prime}-\mathrm{Fe}_{4} \mathrm{~N}$ & $\begin{array}{l}\text { Card: 03:0964 } \\
\text { Card: 03:0958 }\end{array}$ & $3.8123(4)$ & $\begin{array}{c}200-210-311 \\
222\end{array}$ \\
\hline & $\varepsilon-\mathrm{Fe}_{2+\mathrm{x}} \mathrm{N}$ & $\begin{array}{l}\text { Card: 03:0925 } \\
\text { ICSD: } 93173\end{array}$ & $c=4.6568(1)$ & $\begin{array}{c}00.2-10.1-01.2 \\
20.0-04.0\end{array}$ \\
\hline & $\mathrm{CrN}$ & Card: 11-0065 & $4.1214(2)$ & $111-200-220311$ \\
\hline & $\mathrm{CrO}$ & Card: 06-0532 & $8.3518(2)$ & $220-311-440$ \\
\hline
\end{tabular}

$\varepsilon-\mathrm{Fe}_{2+\mathrm{x}} \mathrm{N}(0<\mathrm{x}<1)$

Table 2. Phases, lattice parameters, space group and symmetry for untreated and nitrided AISI 316.

\begin{tabular}{|c|c|c|c|c|}
\hline \multicolumn{5}{|c|}{ AISI 316} \\
\hline Temperature & Phases & JCPDS-ICSD- Reference & Lattice parameter & (hkl) \\
\hline \multirow[t]{2}{*}{ Untreated } & $\gamma$-austenite & Card: 33:0397 & $3.5935(1)$ & $111-200-220$ \\
\hline & $\alpha^{\prime}$-martensite & Card: $35: 1375$ & $2.8831(1)$ & 110 \\
\hline \multirow[t]{2}{*}{$300^{\circ} \mathrm{C}$} & $\gamma$-austenite & Card: 33:0397 & $3.5975(4)$ & $111-200220$ \\
\hline & $\gamma_{N}$-austenite & References $^{10-17}$ & $3.7032(5)$ & $111-200$ \\
\hline \multirow[t]{4}{*}{$400^{\circ} \mathrm{C}$} & $\gamma$-austenite & Card: 33:0397 & $3.5864(8)$ & 111 \\
\hline & $\gamma_{\mathrm{N}}$-austenite & References $^{10-17}$ & & $111-200$ \\
\hline & $\gamma^{\prime}-\mathrm{Fe}_{4} \mathrm{~N}$ & $\begin{array}{l}\text { Card: 03:0964 } \\
\text { Card: 03:0958 }\end{array}$ & $3.8123(1)$ & $200-210$ \\
\hline & $\varepsilon-\mathrm{Fe}_{2+\mathrm{x}} \mathrm{N}$ & $\begin{array}{l}\text { Card: 03:0925 } \\
\text { ICSD: } 93173\end{array}$ & $c=4.7360(3)$ & $00.2-02.0-12.1$ \\
\hline \multirow[t]{4}{*}{$500{ }^{\circ} \mathrm{C}$} & $\gamma$-austenite & Card: 33:0397 & $3.5664(6)$ & 111 \\
\hline & $\gamma^{\prime}-\mathrm{Fe}_{4} \mathrm{~N}$ & $\begin{array}{l}\text { Card: 03:0964 } \\
\text { Card: 03:0958 }\end{array}$ & $3.7749(7)$ & $200-210$ \\
\hline & $\varepsilon-\mathrm{Fe}_{2+\mathrm{x}} \mathrm{N}$ & $\begin{array}{l}\text { Card: 03:0925 } \\
\text { ICSD: } 93173\end{array}$ & $c=4.6871(2)$ & $00.2-02.0-12.1$ \\
\hline & $\mathrm{CrN}$ & Card: 11-0065 & $4.0987(2)$ & $111-200-220-311$ \\
\hline
\end{tabular}

$\varepsilon-\mathrm{Fe}_{2+\mathrm{x}} \mathrm{N}(0<\mathrm{x}<1)$

study, the expanded austenite was considered a cubic structure since this yielded the best fitting, in agreement with literature data ${ }^{14-15}$. The refinement indicates an expansion on the order of $10 \%$ in unit cell volume of the austenitic structure to accommodate the N. Some authors ${ }^{25-26}$ classified the nitrogen-expanded austenite in two types: $\gamma_{\mathrm{N} 1}$ (paramagnetic phase with $\mathrm{N}$ contents $20-26$ at. $\% \mathrm{~N}$ in the surface layer) and $\gamma_{\mathrm{N} 2}$ (magnetic phase with $\mathrm{N}$ contents $4-10$ at. $\%$ in the subsurface layer). These authors suggested that this structure is formed by stress-induced diffusion. The detected structure can be attributed to $\gamma_{\mathrm{N} 1}$ type with lattice parameters of order to 3.7171(4) $\AA$ which is in agreement to with the literature ${ }^{25-26}$.

The structural parameters obtained from analysis of $\mathrm{X}$ ray diffraction of samples nitrided at 400 and $500{ }^{\circ} \mathrm{C}$ are shown in Tables 1 and 2. Both steels treated at $400{ }^{\circ} \mathrm{C}$ present the $\varepsilon-\mathrm{Fe}_{2+x} \mathrm{~N}$ nitride that has hexagonal structure, with $0<x<1$, as the predominant phase. The value of $\mathrm{x}$ varies with steel composition and working temperature being close to 1 . Figure 2 shows the refinement for nitrided samples at $500{ }^{\circ} \mathrm{C}$ for both steels that present a coexistence 
of studied phases. Since a higher number of reflection peaks were observed for $\varepsilon-\mathrm{Fe}_{2+x} \mathrm{~N}$ it is supposed that this phase is predominant in AISI 304 treated at $500{ }^{\circ} \mathrm{C}$, while for AISI 316 the predominant nitride is $\gamma^{\prime}-\mathrm{Fe}_{4} \mathrm{~N}$.

\subsection{Hardness profiles}

Figure 3 shows hardness profiles at shallow tip penetrations for untreated steels and for the different nitriding temperatures. Hardness at the near surface region for untreated AISI 304 corresponds to $\sim 6$ GPa while for untreated AISI 316 the hardness is $\sim 4 \mathrm{GPa}$. At deeper regions the bulk hardness is reached ( $\sim 3.5$ GPa for AISI 304 and $\sim 2$ $\mathrm{GPa}$ for AISI 316). The greater hardness near the surface is due to the mechanical polishing process that induces plastic deformations that will result in fcc to bcc martensitic transformation.

The comparison between hardness profiles for the different steels and working temperatures indicates that (a) in both steels after nitriding at $300{ }^{\circ} \mathrm{C}$ a very similar thin hard layer with hardness around $12-13 \mathrm{GPa}$ at depths less than $200 \mathrm{~nm}$ is formed. At greater

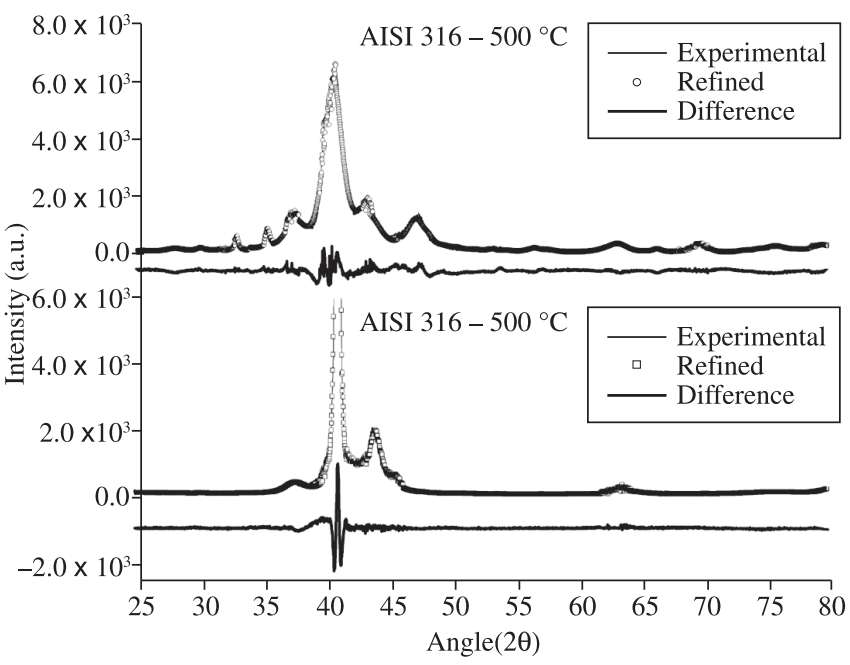

Figure 2. Rietveld refinement for samples AISI 304 (a) and AISI 316 (b) treated at $500^{\circ} \mathrm{C}$.

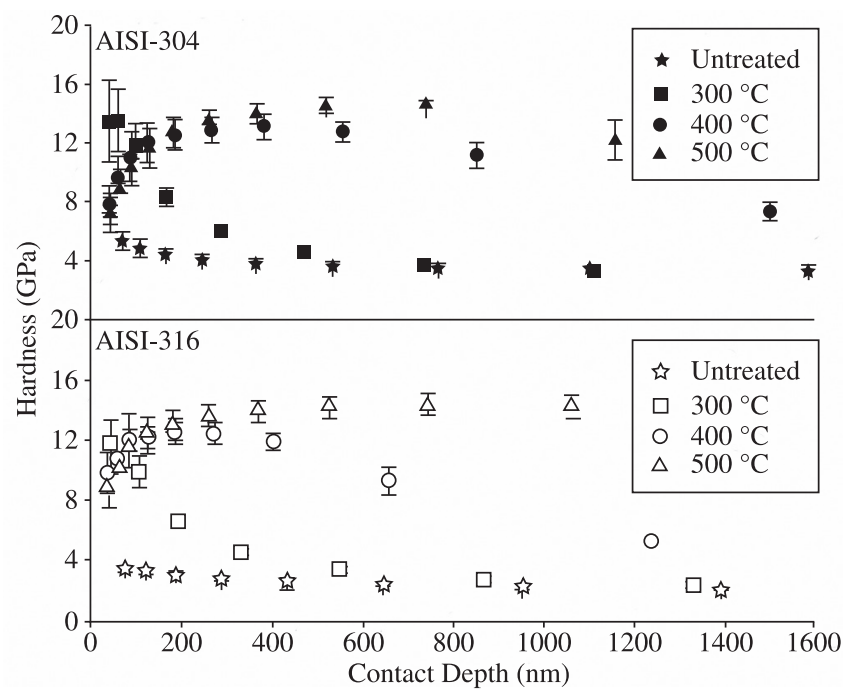

Figure 3. Instrumented indentation hardness profiles of untreated and nitrided samples at the different working temperatures. depths the hardness rapidly drops to its bulk value. (b) A working temperature of $400{ }^{\circ} \mathrm{C}$ promotes thicker hard layers (12-13 GPa). However, for AISI 316 the hardness decreases towards bulk values more suddenly than for AISI 304. (c) Nitriding at $500{ }^{\circ} \mathrm{C}$ produces a thick hard plateau-like layer (12-14 GPa) in both alloys. In the case of AISI 316, the hard plateau extends to deeper regions.

Roughness increases with the working temperature in the GD nitriding process. This roughness influences the hardness measurements obtained by instrumented indentation at shallow tip penetration ${ }^{27-28}$. The low apparent measured instrumented indentation hardness at the near surface region (Figure 3) is attributed then to the roughness. However, after 200 to $300 \mathrm{~nm}$ in depth the hardness reaches an asymptotic maximum value. The asymptotic behavior tends to the actual hardness at deeper regions. The dispersion in hardness can be attributed to the presence of different grain orientations and nitride compositions.

Figure 4 shows conventional Vickers hardness profiles as a function of applied load for the different working temperatures and steels. The Vickers hardness for the samples nitrided at a working temperature of $300{ }^{\circ} \mathrm{C}$ is almost the same as for untreated conditions indicating that the nitrogen diffusion layer is thin. However, for nitriding at $400{ }^{\circ} \mathrm{C}$ the Vickers hardness is higher for AISI 304 than for AISI 316, as also observed in the hardness profiles obtained by instrumented indentation (Figure 3). The nitrided layer in AISI 316 treated at $500{ }^{\circ} \mathrm{C}$ has greater hardness $(14 \mathrm{GPa}$ ) for an applied load of $1 \mathrm{~N}$ than AISI 304 ( $9 \mathrm{GPa})$. Moreover, for the highest applied load $(5 N)$ the bulk hardness is not yet reached in AISI 316. In some measurements there is a large dispersion which could be attributed to indentations performed on different nitrided grains.

The nitrogen diffusion in austenitic steels occurs by a trapping and detrapping mechanism driven by chromium sites in the austenitic structure $^{29}$. Consequently, the deep hard layer observed in AISI 316 nitrided at $500{ }^{\circ} \mathrm{C}$, should be attributed to higher nitrogen diffusivity in this alloy than for AISI 304. It can be supposed that the increase in $\mathrm{N}$ diffusivity at $500{ }^{\circ} \mathrm{C}$ may be induced by the presence of Mo in the AISI 316 alloy that can play a role in the diffusing process, since the $\mathrm{Cr}$ content is almost the same in both steels. The structural analysis indicates the predominant nitride is $\gamma^{\prime}-\mathrm{Fe}_{4} \mathrm{~N}$ for AISI 316, while for AISI 304 the predominant nitride is $\varepsilon-\mathrm{Fe}_{2+\mathrm{x}} \mathrm{N}$. The $\gamma^{\prime}-\mathrm{Fe}_{4} \mathrm{~N}$ phase is

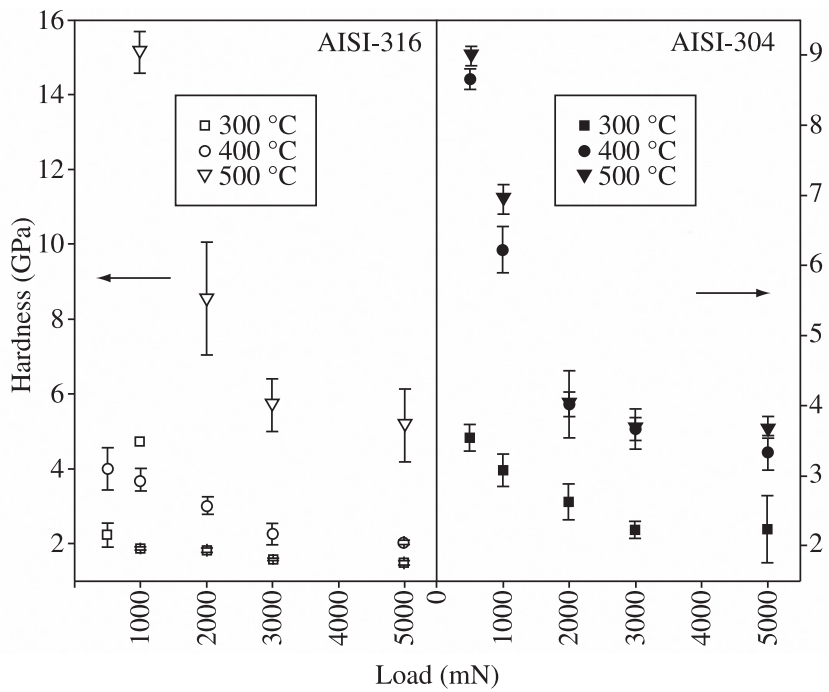

Figure 4. Vickers hardness profiles for AISI 304 and AISI 316 nitrided at different working temperatures. Note the different hardness scales for the steels. 
poorer in $\mathrm{N}$ that the $\varepsilon-\mathrm{Fe}_{2+\mathrm{x}} \mathrm{N}$ phase and this fact also supports the statement that the $\mathrm{N}$ layer is deeper in the AISI 316 alloy.

\subsection{Tribological behavior}

The results of conventional reciprocating sliding tribological test and nanoscratch test are presented in this section.

\subsubsection{Reciprocating sliding}

Figure 5 shows typical friction coefficient profiles for untreated samples and for those nitrided at 300 and $500{ }^{\circ} \mathrm{C}$. The serrated-like behavior for the friction coefficient profiles is attributed to a slipstick process due to the roughness (asperities - see Figure 6) that modifies that ball-surface contact. Despite the presence of asperities, the nitriding process is observed to reduce the friction coefficient value. The stationary regime for the untreated steels is reached after a sliding distance of $\sim 2 \mathrm{~m}$ and friction coefficients around 0.6 . The nitriding process modifies the running-in regime and even for the integrated sliding distance of $9 \mathrm{~m}$, a stationary regime similar to that for untreated samples is not reached. In a previous reported result for AISI 304 nitrided at richer nitrogen atmosphere $\left(\mathrm{N}_{2}: \mathrm{H}_{2}-60: 40\right)$, Foerster et al. ${ }^{9}$ reported similar friction coefficient profiles for high working temperatures.

Figure 6 shows the SEM images of the tracks, at half length, produced by the ball sliding during tribological tests, for both steels

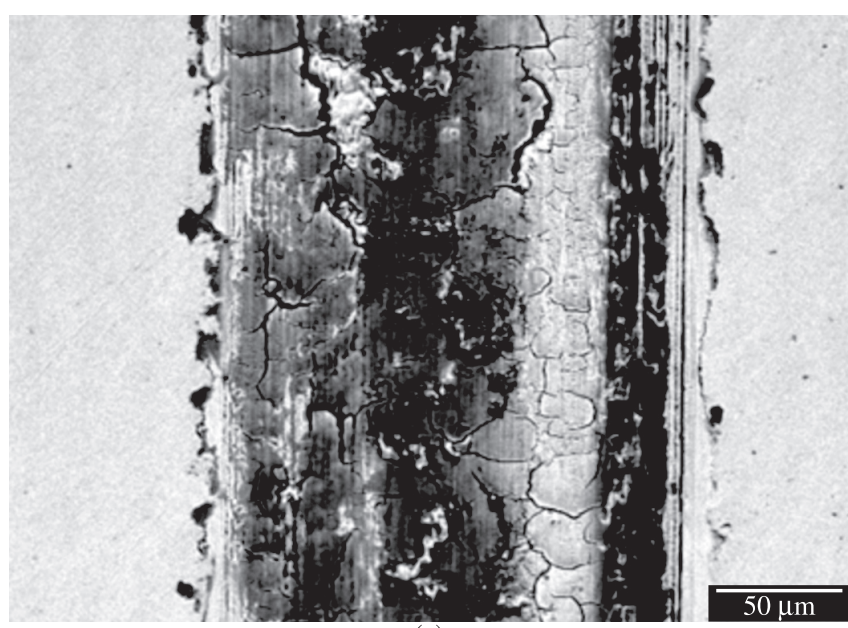

(a)

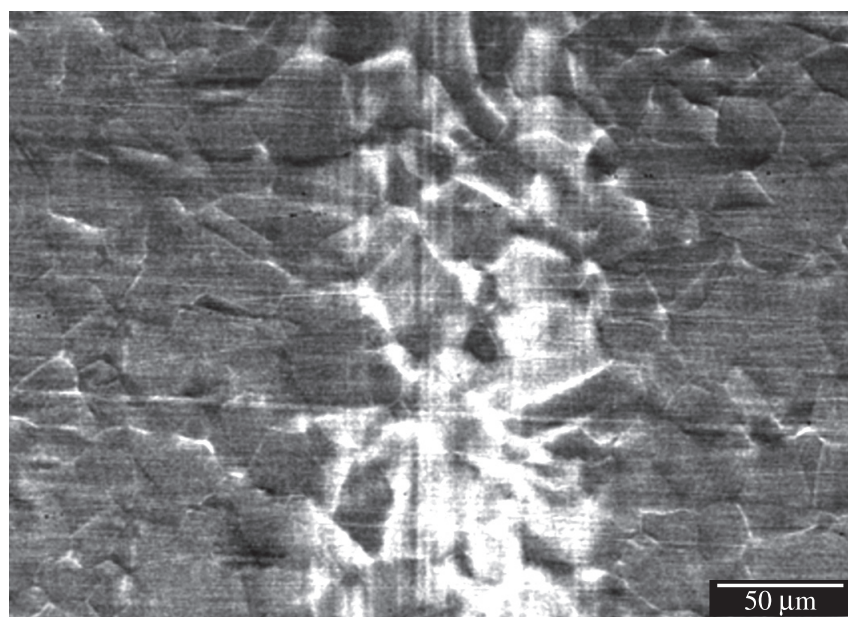

(c) treated at 300 and $500^{\circ} \mathrm{C}$. The surface morphology is similar for both steels treated at $300{ }^{\circ} \mathrm{C}$, with a higher track width when compared to the samples treated at $500{ }^{\circ} \mathrm{C}$. The wear is less pronounced for the highest temperature conditions, a high roughness is also observed, and the asperities are large for AISI 316.

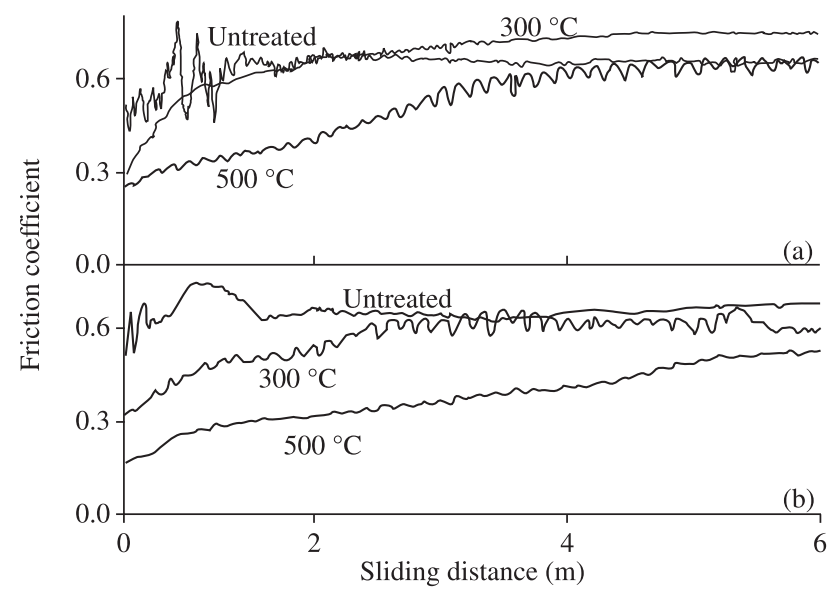

Figure 5. Friction coefficient profiles as a function of sliding distance for AISI 304 (a) and AISI 316 (b) untreated, and for samples nitrided at 300 and $500{ }^{\circ} \mathrm{C}$.

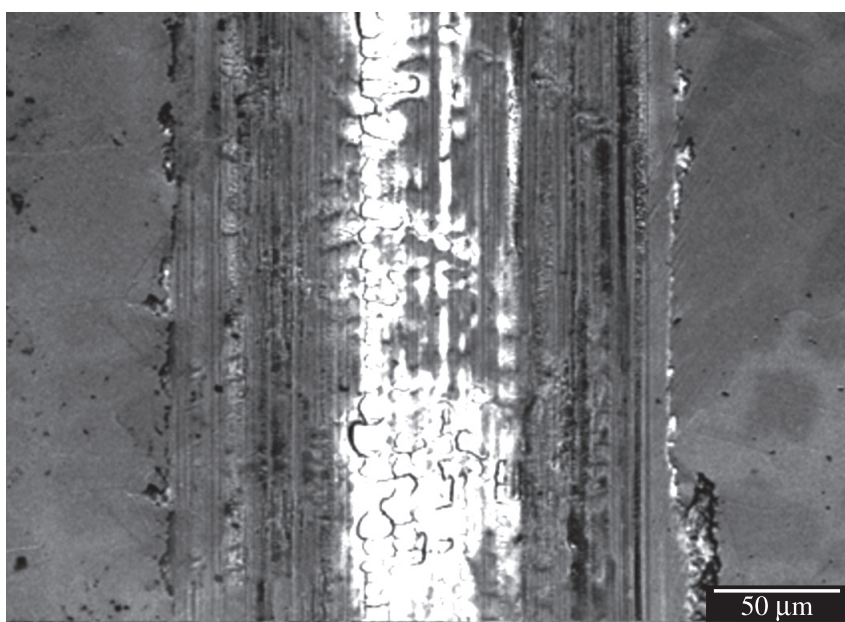

(b)

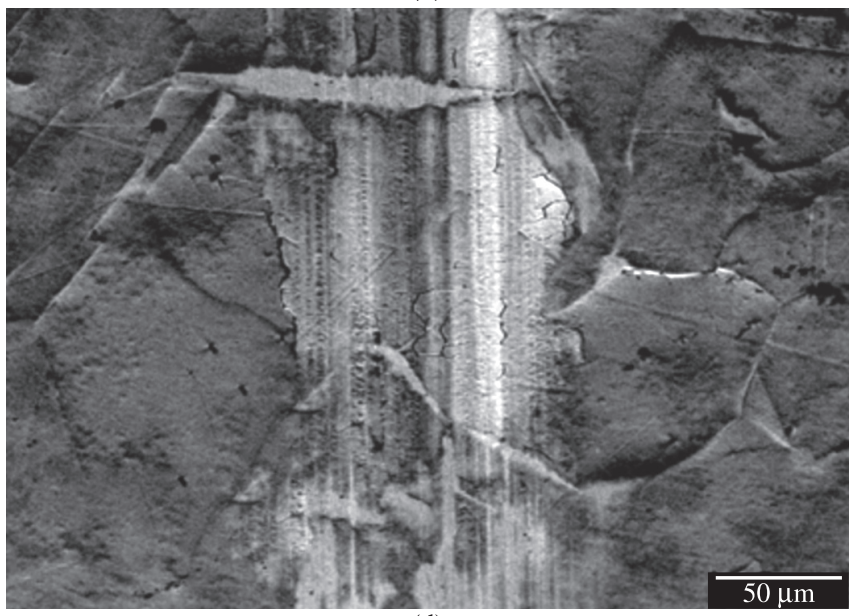

(d)

Figure 6. SEM images of tracks produced by ball sliding during tribological tests. (a) AISI $304-300{ }^{\circ} \mathrm{C}$; (b) AISI $316-300{ }^{\circ} \mathrm{C}$; (c) AISI $304-500{ }^{\circ} \mathrm{C}$ and (d) AISI $316-500{ }^{\circ} \mathrm{C}$. 
Figure 7 shows typical cross-section profiles at the mean track region of the groove produced after the sliding distance of $9 \mathrm{~m}$. For the untreated AISI 304 the groove depth reaches around 2,000 $\mathrm{nm}$ while for AISI 316, this depth reaches $5,000 \mathrm{~nm}$. This fact is correlated to the lower hardness profiles in AISI 316 as shown in Figures 3 and 4. An intensive plastic deformation (pile-up) at the groove border for the untreated condition is observed. The material displacement (pile-up) is due to the ductility of the austenitic structure associated with the mechanisms involved in working hardening after cyclic mechanical deformation. The roughness degree (asperities) that increases by increasing the working temperature can be inferred from the surface profiles obtained by instrumented indentation. The abrasive wear regime with a three-body component is more intense for untreated AISI 304 than for AISI 316 as inferred from the inside groove scars.

Hardness values of about 12 GPa restricted to very shallow region ( 200 nm, see Figure 3) are observed for nitriding at $300{ }^{\circ} \mathrm{C}$ in both steels. However, a significant reduction in the wear is observed as shown by the groove profiles (Figure 7). This reduction is on the order of six times with respect to untreated steels. At the same time, it is observed that the pile-up size (height and width) is drastically reduced when comparing to untreated conditions.

For nitriding temperatures higher than $300^{\circ} \mathrm{C}$, roughness is present at the surface and consequently the actual wear rate cannot be correctly estimated, because the asperities introduce artifacts into the determination of the reference surface. Groove profiles for $400{ }^{\circ} \mathrm{C}$ working temperatures are similar in both steels and they are not shown here.
Moreover, the groove depths $\left(400^{\circ} \mathrm{C}\right)$ are similar that for $300^{\circ} \mathrm{C}$ nitriding and this means that no additional wear improvement takes place. In Figures 6 and 7 it is possible to observe that the roughness degree at $500{ }^{\circ} \mathrm{C}$ is very high. The contact of a large radius hard sphere pressed on a rough surface makes a mechanical deformation on the asperities. The combined effect of mechanical deformation and high hardness reduces the wear, but this effect is difficult to quantify. Initially, wear occurs by smoothing the asperities through a reduction in their height. After that hard precipitates are pulled out producing scars inside the groove by a three-body component mechanism (abrasive wear).

The AISI 316 steel reveals a higher plasticity (high ductility) than AISI 304. The higher content of Ni and Mo presence in AISI 316 may be the origin of this difference, since martensitic phases are more difficult to be induced by the mechanical deformation produced by the ball contact.

\subsubsection{Nanoscratch tests}

Figure 8 shows typical tip penetration profiles for untreated samples and for those nitrided at $400{ }^{\circ} \mathrm{C}$. These curves represent the penetration during and after the loading, taking into account the original surface topography for applied ramping load up to $400 \mathrm{mN}$. In agreement with the tribological tests performed by reciprocating sliding tests (Figure 7), the untreated AISI 316 has the deepest tip penetration in comparing to the AISI 304, which is attributed to the lower hardness. Despite the similar hardness near the surface, AISI

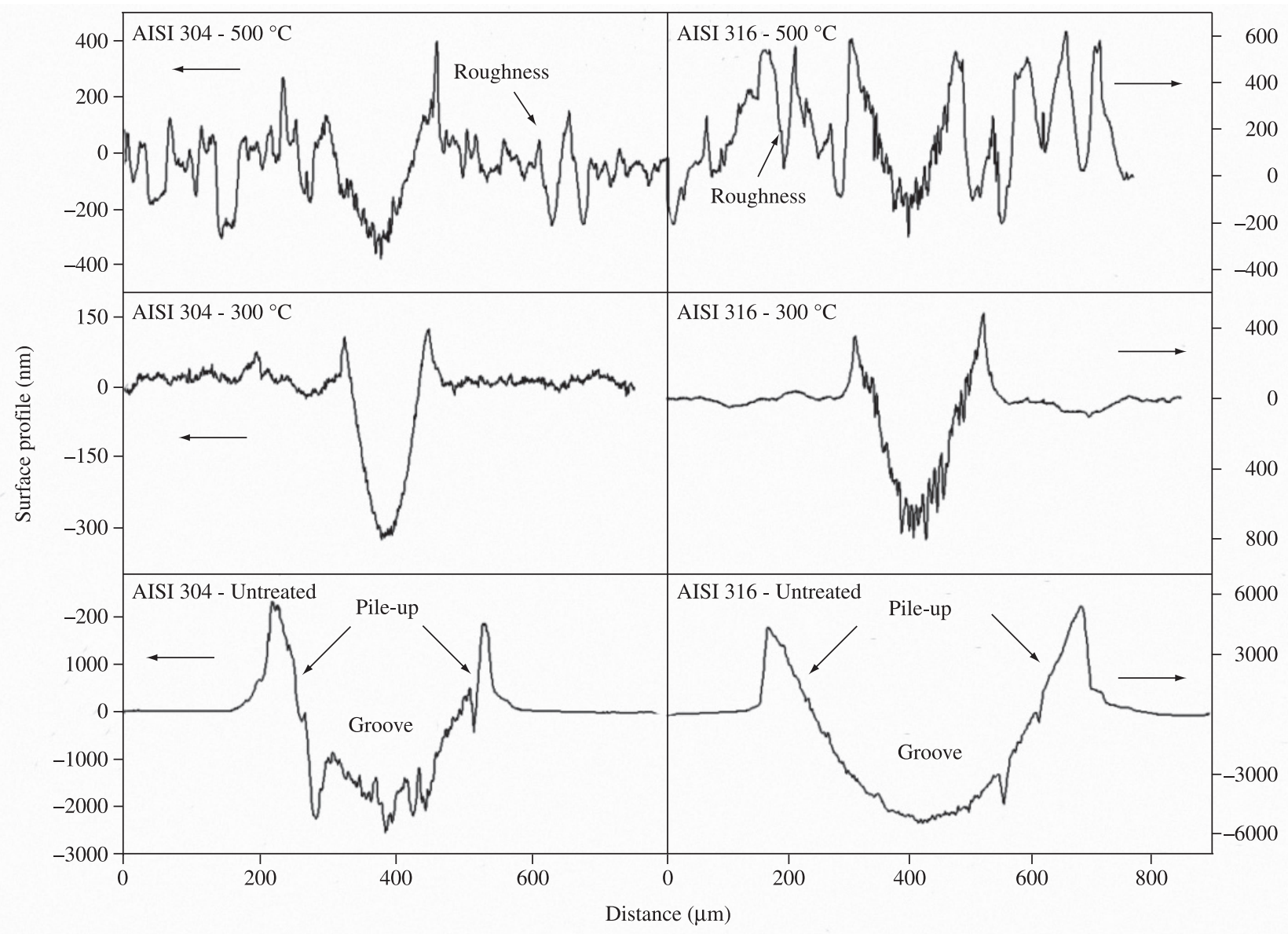

Figure 7. Groove profiles from tribology reciprocating sliding tests for AISI 304 and AISI 316 samples: untreated, and nitrided at 300 and $500{ }^{\circ} \mathrm{C}$. Note the different depth scales. 


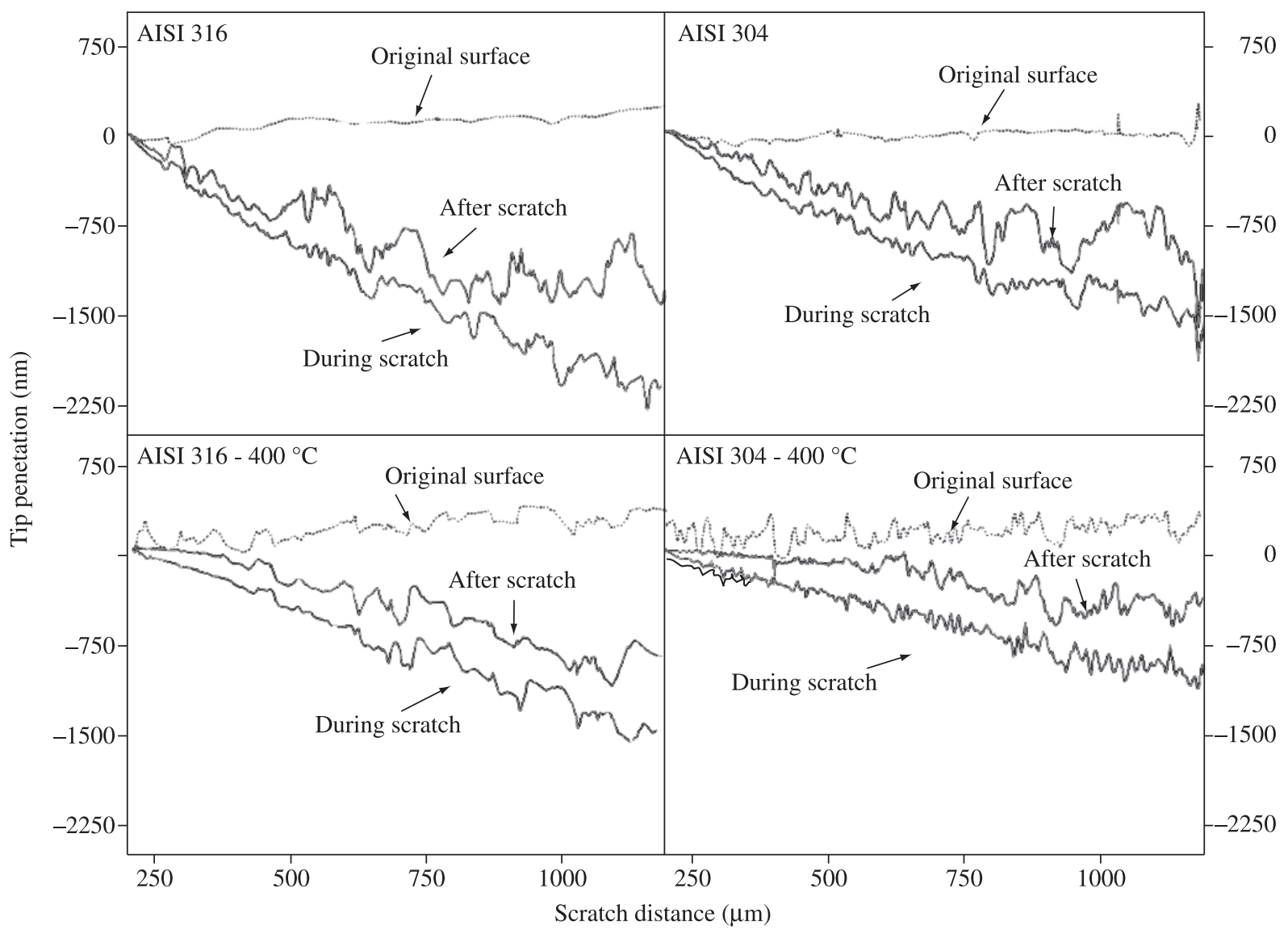

Figure 8. Typical tip penetration profiles produced by nanoscratch tests for AISI 304 and AISI 316 samples: untreated, and nitrided at $500{ }^{\circ} \mathrm{C}$. Note the different depth scale.

316 has lower hardness at depths of 1,000 nm than AISI 304 as shown in Figure 3.

The AISI 316 nitrided at $400{ }^{\circ} \mathrm{C}$ shows a deeper tip penetration during the scratching, indicating lower hardness as observed in hardness profiles shown in Figures 3 and 4.

The tip geometry contact for nanoscratch tests is the same as for hardness measurements, but the stress distribution is modified. Plastic deformations are concentrated at shallow depths under regions around the tip edges due to the stress distribution. In contrast, the elastic modulus is similar for all nitriding conditions for thin modified layers, since the elastic field extends for a long distance including the surface layer and large region within the bulk. Consequently the elastic recovery after scratching is more influenced by the bulk than by the elastic properties of the modified layer. During contact, compliance is determined by the combined elastic response of the modified layer and of the bulk.

\section{Conclusion}

This investigation of the nitriding process in AISI 304 and AISI 316 steels at 20:80 $-\mathrm{N}_{2}: \mathrm{H}_{2}$ atmosphere and working temperatures ranging from 300 to $500{ }^{\circ} \mathrm{C}$ showed that a complex modified layer of embedded nitride precipitates is produced in the austenitic matrix at working temperatures higher than $300{ }^{\circ} \mathrm{C}$ in both alloys. AISI 316 favor the $\gamma^{\prime}-\mathrm{Fe}_{4} \mathrm{~N}$ phase as the major contribution while AISI 304 favors the $\varepsilon-\mathrm{Fe}_{2+\mathrm{x}} \mathrm{N}$ phase. In addition, a $\mathrm{CrN}$ phase is observed for treatments at $500{ }^{\circ} \mathrm{C}$. In samples nitrided at $300{ }^{\circ} \mathrm{C}$, slightly higher expanded austenite content is present in AISI 316 than in AISI 304 . At high working temperatures $\left(\mathrm{T}>300^{\circ} \mathrm{C}\right)$, AISI
316 has lower roughness than AISI 304. Austenitic steels AISI 304 and AISI 316 have maximum hardness around $14 \mathrm{GPa}$, which is in agreement with literature data, which report surface hardness not surpassing 15-16 GPa for almost all ion nitriding processes. The thickest hard layer is obtained for nitriding process at $500{ }^{\circ} \mathrm{C}$ in AISI 316 . The wear can be reduced by a factor of six for $300{ }^{\circ} \mathrm{C}$ nitriding in both alloys. The wear reduction is similar for treatments at $400{ }^{\circ} \mathrm{C}$. Surfaces treated at $500{ }^{\circ} \mathrm{C}$ show high roughness due to the presence of asperities. The sliding process is initially restricted to compacting asperities and after equalizing roughness, wear starts to take place. Due to asperities the wear cannot be measured correctly from groove profiles since the baseline of the original surface is not clearly defined to obtain the difference between the track depth and adjacent surface to measure the worn wear.

\section{Acknowledgements}

We would like to acknowledge the Brazilian agency CNPq for financial support. We are also grateful to Dr. Adilson Chinelatto UEPG for the SEM images.

\section{References}

1. Pelletier J, Anders A. Plasma-based ion implantation and deposition: a review of physics, technology, and applications. IEEE Transactions of Plasma Science. 2005; 33(6):1944-1959.

2. Czerwiec T, Renevier N, Michel H. Low-temperature plasma-assisted nitriding. Surface and Coatings Technology. 2000; 131(1-3):267-277. 
3. Christiansen T, Somers MAJ. Low temperature gaseous nitriding and carburising of stainless steel. Surface Engineering. 2005; 21(5-6):445-455.

4. Mändl S, Fritzsche B, Manova D, Hirsch D, Neumann H, Richter E. et al. Wear reduction in AISI 630 martensitic stainless steel after energetic nitrogen ion implantation. Surface and Coatings Technology 2005; 195(2-3):258-263.

5. Sousa RRM, Araujo FO, Barbosa JCP, Ribeiro KJB, Costa JAP, Alves Jr. C. Nitriding using cathodic cage technique of austenitic stainless steel AISI 316 with addition of CH4. Materials Science and Engineering A. 2008; 487(1-2):124-127.

6. Ribeiro KJB, Sousa RRM, Araujo FO, Brito RA, Barbosa JCP, Alves Jr. C. Industrial application of AISI 4340 steels treated in cathodic cage plasma nitriding technique. Materials Science and Engineering A. 2008; 479(1-2):142-147.

7. Basso RLO, Candal RJ, Figueroa CA, Wisnivesky D, Alvarez F. Influence of microstructure on the corrosion behavior of nitrocarburized AISI H13 tool steel obtained by pulsed DC plasma. Surface and Coatings Technology. 2009; 203(10-11):1293-1297.

8. Gontijo LC, Machado R, Miola EJ, Casteletti LC, Alcantara NG, Nascente PAP. Study of the $S$ phase formed on plasma-nitrided AISI 316L stainless steel. Materials Science and Engineering A. 2006; 431(1-2):315-321.

9. Foerster CE, Serbena FC, Silva SLR, Lepienski CM, Siqueira CJM, Ueda M. Mechanical and tribological properties of AISI 304 stainless steel nitrided by glow discharge compared to ion implantation and plasma immersion ion implantation. Nuclear Instruments and Methods in Physics Research B. 2007; 257(1-2):732-736.

10. Alves C, Rodrigues JA, Martinelli AE. Growth of nitrided layers on $\mathrm{Fe}-\mathrm{Cr}$ alloys. Materials Science and Engineering A. 2002; 279(1-2):10-15.

11. Saha R, Nix WD. Effects of the substrate on the determination of thin film mechanical properties by nanoindentation. Acta Materialia. 2002; 50(1):23-38.

12. Lepienski CM, Foerster CE. Nanomechanical Properties by Nanoindentation In: Nalwa HS. (Eds.). Encyclopedia of nanoscience and nanotechnology. Stevenson Ranch - USA: American Scientific Publishers; 2004. Vol. 7, p. 1-20.

13. Oliver WC, Pharr GM. Measurement of thin film mechanical properties using nanoindentation. Materials Research Bulletin. 1992; 17(7):28-33.

14. Hoeft D, Latella BA, Short KT. Residual stress and cracking in expanded austenite layers. Journal of Physics Condensed Matter. 2005; 17(23):3547-3358.

15. Valencia R, Lópes-Callejas R, Munoz-Castro A, Barocio SR, Chavez E, Godoy-Cabrera O. Nitriding of AISI 304 stainless steel by PIII in
DC and RF toroidal discharges. Brazilian Journal of Physics. 2004; 34(4B):1594-1597.

16. Abd El-Rahman AM, El-Hossary FM, Fitz T, Negm NZ, Prokert F, Pham MT. et al. Effect of $\mathrm{N}_{2}$ to $\mathrm{C}_{2} \mathrm{H}_{2}$ ratio on r.f. plasma surface treatment of austenitic stainless steel. Surface and Coatings Technology 2004; 183(2-3):268-274.

17. Sun Y, Haruman E. Influence of processing conditions on structural characteristics of hybrid plasma surface alloyed austenitic stainless steel. Surface and Coatings Technology 2008; 202(17):4069-4075.

18. Manova D, Mändl S, Neumann H, Rauschenbach B. Influence of grain size on nitrogen diffusivity in austenitic stainless steel. Surface and Coatings Technology 2007; 201(15):6686-6689.

19. Liang W, Juncai S, Xiaolei X. Low pressure plasma arc source ion nitriding compared with glow-discharge plasma nitriding of stainless steel. Surface and Coatings Technology 2001; 145(1-3):31-37.

20. Collins GA, Hutchings R, Short KT, Tendys J, Li X, Samandi M. Nitriding of austenitic stainless steel by plasma immersion ion implantation. Surface and Coatings Technology 1995; 74(1):417-424.

21. Blawert C, Kalvelage H, Mordike BL, Collins GA, Short KT, Jirásková Y. et al. Nitrogen and carbon expanded austenite produced by PI3. Surface and Coatings Technology 2001; 136(1-3):181-187.

22. Rietveld HM. Line profiles of neutron powder-diffraction peaks for structure refinement. Acta Crystallographic 1967; 22(1):151-152.

23. Carvajal JR. An introduction to the program FullProf 2000. Saclay France: Lab. Leon Brillouin; 2000.

24. Fewell MP, Priest JM. High-order diffractometry of expanded austenite using synchrotron radiation. Surface and Coatings Technology 2008; 202(9):1802-1815.

25. Williamson DL, Davis JA, Wilbur PJ. Effect of austenitic stainless steel composition on low-energy, high-flux, nitrogen ion beam processing. Surface and Coatings Technology 1998; 103(1):178-184.

26. Baranowska J, Franklin SE, Pelletier CGN. Tribological behaviour and mechanical properties of low temperature gas nitrided austenitic steel in relation to layer morphology. Wear. 2005; 259(4-5):432-438.

27. Souza GB, Foerster CE, Silva SRL, Serbena FC, Lepienski CM, Santos CA. Hardness and elastic modulus of ion-nitrided titanium obtained by nanoindentation. Surface and Coatings Technology. 2005; 191(1):76-82.

28. Souza GB, Foerster CE, Silva SLR, Lepienski CM. Nanomechanical properties of rough surfaces. Materials Research. 2006; 9(2):159-163.

29. Parascandola S, Moeller W, Willianson DL. The nitrogen transport in austenitic stainless steel at moderate temperatures. Applyed Physics Letters. 2000; 76(16):2194-2196. 